\title{
The influences of the TPS model and reading interests on writing skills of explanatory text of class VIII student
}

\author{
Lidya Atsari ${ }^{1}$, Agustina Agustina ${ }^{2}$, Novia Juita ${ }^{3}$ \\ ${ }^{123}$ Universitas Negeri Padang, Padang - Indonesia, (lidya2892@gmail.com)
}

\begin{abstract}
This research aims to describe the influences of TPS model and reading interest of class VIII student of SMP Negeri 31 Padang about their skills of writing explanatory text. This research type is quantitative research with $2 \times 2$ factorial experiment design. The population of this research is all students of class VIII SMP Negeri 31 Padan. The data collects by using two methods. The analysis and discussion of the data apply descriptiveanalysis method in accordance with the concept of experimental research. Based on the research the writer concludes that from explanatory text writing, the students who have high reading interest and low reading interest whom applies TPS model have higher reading interest than the students that using conventional learning methods. Furthermore, there is no interaction between TPS model with reading interest in influencing the learning outcomes of the students' in explanatory text writing skills.
\end{abstract}

Keywords: influence, TPS , reading interest, writing skill

\section{Introduction}

Writing is one of four aspects of language skills. As one of the linguistic aspect, writing activity is inseparable in the learning process experienced by students during their study. Write down a very important lesson is a way to be mastered by students (Hyland, 2007). One of the writing skills that must be mastered in accordance with the Indonesian language in the Curriculum 2013 is the skill of writing explanatory text. The skill of writing an explanatory text is a form of writing that contains an explanation of the process of enhancing a phenomenon or event, both natural and social phenomena. The explanatory text has a social purpose to interpret the process of emerging or rising an event or phenomenon related to nature, social and culture.

Based on the observations and interviews conducted on Indonesian VIII grade teacher of SMP Negeri 31 Padang, there are several problems that arise in learning the skills of writing explanatory text. (1) Students are less enthusiastic to write because they think writing is a difficult job. This is in accordance with research conducted by Sibarani (2007) which states that writing skills is the most difficult language skills to master because writing is a very complicated cognitive process. (2) Teachers' learning model is less effective. (3) Student reading interest is low. This causes students have not been able to pour ideas, concepts, thoughts in the form of writing because the knowledge is still minimal. 
So far, the learning of explanatory text writing skills has been done conventionally. Students listen to the theories described by the teacher, then the students are asked to re-read the theory of writing an explanatory text. Next the students see the sample and finally the students are assigned to make the paragraph or discourse of explanatory text either directly or by continuing the existing writing. This conclusion is reinforced by the fact that varied media or learning resources have not been raised by teachers. Learning resources outside the teacher that can be utilized by students that is textbooks and exercise bahasa Indonesia book.

One solution to overcome these problems is to use a learning model that can motivate students to develop the knowledge they have in learning and able to raise the spirit of student learning. Learning model in question is an innovative learning model that makes students active and creative so that the learning atmosphere is more conducive. One of the learning model that can be applied by students in writing especially writing explanatory text is cooperative learning model Think Pair Share (TPS). In the following description, TPS stands for Think Pair Share.

According to Suyatno (2009, p.54), TPS is a cooperative learning model that has explicitly defined procedures, giving students more time to think deeply about what is explained or experienced (thinking, answering, and helping each other). At each stage of learning TPS can not be separated from the interaction of students with other students because they face the same problems and require the best solution to the problems they face. In the thinking phase, the teacher asks questions or issues related to the lesson, then the students are asked to think about the question or issue independently for a while. This process can help students to generate ideas or ideas that exist in their minds, so as to spur student creativity.

In the pairing stage, students will help each other. Students with a somewhat lower ability will feel motivated and more active because they do not want to rely on more capable friends. While more capable students will feel proud and motivated to share their knowledge. So, this stage can encourage students to be more confident and courageous to put their ideas or thought into writing. It is expected that at this stage students no longer assume that writing is a difficult job.

In the sharing stage, students can also see the motivation when reporting the results of work in front of the class. Students will retain their good name and try to argue scientifically. So the students will try to find the most relevant problem solving on every discussion of the problem posed.

The TPS model has been used as a learning model applied in various studies such as in Indonesia by Sanjaya (2013), Usman (2015), and Efendi and L.P Artini (2013), India by Dol (2014), and Jordan by Hamdan (2017). The results of this study indicate that the TPS model has a better impact compared with the learning using conventional model. In addition, the TPS model gives students the freedom to express their views without fear and doubt.

In addition to the learning model, other factors that cause the low writing skills of students' explanatory text is the low interest in reading owned by students. The reading and writing ability of Indonesian students is at the bottom of the list when compared to Asian children (Supriyoko, 2004). Research conducted by the IEA Study of Reading Literacy (Elly, 1992) and Progress in International Reading Literacy Study (PIRLS) (Baer, et al, 2007) concluded that students' reading ability in Indonesia is still very low. Meanwhile, according to the study of Programe For International Student Assessment (PISA) mentioned, the literacy culture of Indonesian society in 2012 the second worst of 65 countries studied, the world of Indonesia ranks 64th out of 65 countries (Republika. Co.id.15/12 / 16). That is, the literacy culture of Indonesian society far less with other countries.

Based on interviews with teachers of Indonesian language subjects of class VIII SMP N 31 Padang, Mrs. Nelwati MI, S.Pd., obtained information that many students who are less interested to read. When observations are made in the school library, there are few students who visit the library 
because they spend more time playing. In addition, factors that affect reading interest of students is the lack variation of books in the school library.

Implementation of cooperative learning model of TPS type is expected to realize the students' competence to be better, especially in writing explanatory text. In addition, the reason researchers chose SMP Negeri 31 Padang as the object of research is also caused by research on the influence of cooperative learning model of TPS type and interest in reading to the skills of writing explanatory text has not been done in the school. Researchers want to know whether there is a significant influence the use of cooperative learning model of TPS type and interest in reading skills writing text explanation of students of class VIII SMP Negeri 31 Padang.

\section{Method}

This type of research is quantitative research because in this study many are required to use numbers, ranging from data collection, interpretation of the data, and the appearance of the results (Arikunto, 2013, p.27). Figures in this study is the score questionnaire reading habits as well as scores and grades of writing skills text explanation of students in class VIII SMP Negeri 31 Padang. Meanwhile, the research method applied is experimental method. Riduwan (2011: 50) revealed that experimental research is a study that seeks to find a certain variables influence on other variables in tightly controlled conditions.

This type of experiment is a quasi experiment. This study will look at the effect of a treatment on the variables with two sample groups, ie, experiments and control groups. The experimental group is a group of students who gain learning using a TPS type cooperative model. Control groups are students who gain learning using conventional learning models. The design used is $2 \times 2$ factorial design. Factorial design is the most efficient design to investigate the effects of two or more factors (Suwanda, 2011: 145).

The population of this study is all students of class VIII SMP Negeri 31 Padang registered academic year 2016/2017. Grade VIII students are spread into eight classes with 249 people. The sample was taken by purposive sampling technique. According to Arikunto (2008, p.139), purposive technique is done by taking the subject is not based on strata, random or area but based on the existence of a certain purpose. Based on the analysis requirements test, class VIII.2 and class VIII.3 which each class amounted to 30 people, were selected as research samples because this class is a class that has a similar ability and the two classes are homogeneous and have the smallest standard deviation .

Technique of data analysis conducted in this research is as follows. (1) Questionnaire of reading interest. First, add up the total score of the statement. Second, sort the questionnaire scores ranging from highest score to lowest score. Third, classifying students' reading interest into two groups, those with high reading interest and low reading interest groups (Arikunto, 2008, p.261). Respondents in the top $27 \%$ were classified as high reading students and the lowest $27 \%$ were classified as low reading students. (2) The performance test. First, change the score to a value based on the PAP (Benchmark Reference Assessment). To change the score to a value, the formula used is the percentage formula. Second, to convert students 'explanatory text writing skill based on benchmark 10. Third, describe the frequency distribution of students' writing skill. Fourth, display the data in the form of histogram. Fifth, perform hypothesis testing. 


\section{Results and Discussion}

The result of data analysis of writing skill of explanation text of grade VIII students in SMP Negeri 31 Padang observed showed that students who were taught by TPS model as a whole got good value. This can be seen from the group of students who have high reading interest as well as groups of students who have low reading interest. The discussion will be described on four principal studies, as follows.

1. Writing Skills of Student Text Explained by Using TPS Learning Model and Conventional Learning Model

The tests were conducted in the experimental class and control class. The form of the test is the same as the two classes and there is no difference in terms of the question form. The test is done in the form of performance test of explanatory text writing skill. This test aims to see the difference and influence of TPS model on the result of writing skill of explanation text of students of class VIII SMP Negeri 31 Padang. During the learning process, both classes are given different treatment. The experimental class presented the material using the SMT model while the control class uses the conventional model. The results of the first hypothesis test show that the overall result of writing skills of explanatory text of students using TPS model is higher than the writing skill of students' explanation taught using conventional learning model. The value obtained by the students in the experimental class is higher than the value obtained by the students in the control class.

In addition, there is an average difference between the experimental class and the control class. The average writing skill of the experimental class is higher than the control class. This is due to the effect of the treatment given to the experimental class.

This is also seen in Sanjaya's (2013) study entitled "Think Pair Share as an Effective Technique to Enhance the Students' Achievement on Writing Descriptive Text". The results show that this TPS model creates a good environment in learning to write descriptive text in which students become active in the writing process, focus their thoughts on teacher explanations, and share in teams and their partners and then succeed individually. In individual work, students can increase their confidence to complete the job because it has been discussed in teams and couples.

Based on the findings and data analysis conducted it can be concluded that there is influence of TPS model on writing skill of student explanation. This is evidenced from the results of the writing test of explanatory text of experiment class students higher than the control class students. The experimental class students were given treatment in the form of TPS model while the control class used conventional learning.

2. Text Writing Skill of Students Who Have High Read Interest Taught by Using TPS Model and Conventional Learning Model

The result of the second hypothesis test shows that writing skills of explanatory text of students who have high reading interest are taught using a TPS model is better than the ability to write explanatory text students with high reading interest are taught using conventional learning model. The value obtained by the students in the experimental class is higher than the value obtained by the students in the control class.

Learning using a TPS model, students are stimulated to think critically, actively, and can solve problems encountered. It is perfect for students who have high reading interest. In accordance with Ibrahim's opinion (2000, p.26) TPS type cooperative learning is a structural model that has explicitly applied procedures to give students longer time to think, answer, and help each other. That is, teachers provide opportunities for students to develop their creativity with various steps. The role of teachers only as mentors, drivers, facilitators so that students develop themselves, try their own, and find yourself some specific concepts. Students can develop it into a principle in their own language. 
Students who have high reading interest will automatically have a high knowledge so it will be easy to follow every phase in the TPS model. Indirectly, students who have high reading interest will be easy to formulate, seek, and analyze any problems given during the learning process because it already knows the ins and outs of the problem from the references that have been read.

Reading is an attempt to improve writing skills. Because by reading we can pour the ideas we have into a work. Students who have more insight, able to analyze the topic of problems to be written from different angles. In addition, students will have vocabulary treasuries and sentences that are many and ready to be written into a writing, including explanatory texts.

3. Students Explanatory Text Writing Skills with Low Reading Interests Taught with the TPS Model and Conventional Learning Model

The results of the third hypothesis test show that the students' reading-low explanatory text writing skills are higher than those with low reading interest taught using conventional learning models. The value obtained by the students in the experimental class is higher than the control class.

In learning with TPS model students with low reading interest can be helpful in writing explanatory text. This is because the TPS model develops the cognitive structure of students who have low reading interest, thus encouraging the improvement of writing ability of explanatory text.

In learning with conventional models students are placed as learning objects that act as passive recipients of information, learning more individually, theoretically, and abstract. Knowledge is conjugated by others and obtained through memorization and exercises. This makes students who have low interest in reading is not interested to follow the learning of Indonesian because it is less interest with learning styles that use the conventional model.

In accordance with the previously described, although students who have low reading interest in the experimental class higher the value of explanatory text writing skills compared with the value of explanatory text writing skills control. Increased interest in reading of the class needs to be done. This is because the interest of reading indirectly affect the skills of students in writing, especially writing an explanatory text. Because by reading the students will get the information and easy to pour it into writing explanatory text. Text explanation is a text that contains an explanation of the process of occurrence of a phenomenon or event, both natural and social phenomena and culture scientifically. Therefore, the more students read, the more information will be presented in the explanatory text.

4. Interaction between Reading Interest and the TPS Learning Model in Influencing Explanatory Text Writing Skills

Interaction occurs when the effects of one factor depend on the other factor in influencing something, this is in accordance with Irianto's opinion (2014, p.225). This means that each factor between the TPS model and reading interest is interdependent with each other in influencing the writing skills of the student's explanatory text. The process of interaction between these variables can be explained as follows.

Based on the results of two-way anava for testing the fourth hypothesis can be concluded that there is no interaction between the TPS model with reading interest in affecting explanatory text writing skills. As mentioned earlier, the interaction is the effect of the treatment of a particular learning model on a group of students with a specific reading interest. However, reading interest may not necessarily determine success in writing explanatory text skills. Many other factors as a support, such as intelligence, ability, talent, and others. In addition, teacher readiness factor in using the TPS model in the learning process of writing explanatory text will also affect the writing skills of students explanation text.

In addition, writing skills are certainly not only influenced by reading interest. Writing skills are not naturally acquired, but must go through learning and practice (Wagiran and Doyin, 2005, p.2). 
This means even if someone has a high reading interest but if not accompanied by writing exercises, not necessarily writing skills will be good anyway.

There is no interaction between the TPS model and reading interest can also be seen from the average of explanatory text writing skills. This happens on both levels of reading interest, both high and low are equally taught using the TPS model. The average writing skill score of students with high reading and low interest in the experimental class is higher than those with high reading and low interest in the control class.

The average difference in the experimental and control classes was observed in the students having high reading interest taught using the TPS model having an average of 93.92 while the students taught with the conventional model had an average equal to 84.20. Students with low reading interest in the experimental class taught using the TPS model had an average of 79.33, whereas students with low reading interest in the control class taught using the conventional learning model was 68.23. From the column side the absence of interaction gives the meaning that in the TPS model among students who have high reading interest and low reading interest there is no difference in writing skills of explanatory text and the same applies when viewed on conventional learning model.

There is no interaction, it can be concluded that each factor of the TPS model and reading interest are not interdependent in each other in influencing the learning outcomes of explanatory text writing skill and control class. However, the TPS model appears to be more effectively applied to both levels of interest in reading. In other words, the TPS model can be applied to students who have a high reading interest and can also be applied to students who have low reading interest.

\section{Conclusions}

Based on the data analysis and discussion, it can be concluded that the TPS model influences the learning outcomes of writing explanatory text. The result of this research can be concluded that the result of writing skill of explanation of students who have high reading interest and low reading interest which is taught using TPS model is higher than students taught using conventional learning method. Furthermore, there is no interaction between learning model (TPS and conventional) with reading interest (high and low) in influencing writing skill of class VIII students of SMP Negeri 31 Padang.

\section{Acknowledgments}

This article was written as one of the requirements to meet some requirements to obtain Master of Education degree in Indonesian Language and Literature Education Program, State University of Padang. Therefore, thanks go to the mentors and contributors of the thesis who have helped to provide criticism, suggestions, or feedback. Furthermore, thanks go to reviewers who have read, corrected, and provided input to this research article.

\section{References}

Arikunto, S. (2008). Dasar-dasar evaluasi pendidikan. Jakarta: Bumi Aksara.

Arikunto, S. (2013). Prosedur penelitian: suatu pendekatan praktik. Jakarta: Rineka Cipta.

Baer, J., Baldi, S., Ayotte, K., \& Green, P. J. (2007). The reading literacy of US fourth-grade students in an international context: results from the 2001 and 2006 progress in international reading literacy study (PIRLS). Washington, DC: National Center for Education Statistics, Institute of Education Sciences, U.S. Department of Education. 
Dol, S. M. (2014). “TPS(Think-Pair-Share) : an active learning strategy to teach theory of computation course". International Journal of Education Research and Technology. 5, (4).

Efendi, K. S., Artini L. P. (2013). "Pengaruh model pembelajaran kooperatif tipe Think Pair and Share terhadap kemampuan berbicara bahasa Inggris ditinjau dari tingkat kreativitas siswa". e-Journal Program Pascasarjana Universitas Pendidikan Ganesha. (2).

Elly, W. B. (1992). How in ihe world do students read, IEA Ssudy of reading literacy. Hamburg: The International Association for the Evaluation of Education Achivement.

Hamdan, R. K. A. (2017). "The effect of (think - pair - share) strategy on the achievement of third grade student in sciences in the educational district of Irbid". Journal of Education and Practice. 8, (9).

Hyland, K. (2007). "Understanding writing: exploring texts, writer, and readers". Journal of the British Assn of Teacher of Japanese. (8), 63-74.

Ibrahim, M. (2000). Pembelajaran kooperatif. Surabaya: University Press Program Pascasarjana.

Irianto, A. (2004). Statistik pendidikan. Gadjah Mada: University Press.

Republika. (2014). Literasi Indonesia sangat rendah. Artikel.

Riduwan. (2005). Belajar mudah penelitian anak untuk guru, karyawan, dan penelitian pemula: Bandung: Alfabeta.

Sanjaya, D. (2013). “Think pair share as an effective technique to enhance the students' achievement on writing descriptive text". English Language Teaching. 6, (12).

Sibarani, B. (2007). Penerapan proses kognitif dan terapi cognitive blocking dalam peningkatan kualitas pembelajaran menulis. Jurnal Diksi. 14, (2), 78-102.

Supriyoko. (2004). Kebangkitan pendidikan kita. Kedaulatan Rakyat. Artikel.

Suwanda. (2011). Desain eksperimen untuk penelitian ilmiah. Bandung: Alfabeta.

Suyatno. (2009). Menjelajah pembelajaran inovatif. Surabaya: Masmedia Buana Pustaka.

Usman, A. H. (2015). "Using the think pair share strategy to improve students' speaking ability at Stain Ternate". Journal of Education and Practice. 6, (10).

Wagiran dan Doyin. (2005).Curah gagasan pengantar penulisan karya ilmiah. Semarang: Rumah Indonesia. 